\title{
A study of ion exchange at the poly(butyl viologen)-electrolyte interface by SECM
}

\author{
Chih-Yu Hsu ${ }^{\text {a }}$, V.S. Vasantha ${ }^{a}$, Kuo-Chuan Ho ${ }^{\mathrm{a}, \mathrm{b}, *, 1}$ \\ a Department of Chemical Engineering, National Taiwan University, Taipei 10617, Taiwan \\ ${ }^{\mathrm{b}}$ Institute of Polymer Science and Engineering, National Taiwan University, Taipei 10617, Taiwan
}

\section{A R T I C L E I N F O}

\section{Article history:}

Received 31 August 2007

Received in revised form 15 January 2008

Accepted 24 February 2008

Available online 4 March 2008

\section{Keywords:}

Charge compensation

EQCM

Ion exchange

Poly(butyl viologen)

Scanning electrochemical microscopy

(SECM)

\begin{abstract}
A B S T R A C T
In this work, the ion exchange characteristics of poly(butyl viologen) (PBV) thin films on a platinum electrode has been investigated by cyclic voltammetric (CV) scans. Since ferrocyanide anions $\left(\mathrm{Fe}(\mathrm{CN})_{6}{ }^{4-}\right)$ were added during the polymerization of the PBV thin-film for its stability, $\mathrm{Fe}(\mathrm{CN})_{6}{ }^{4-}$ could form charge transfer complex with monomer and co-deposited with polymer. Scanning electrochemical microscopy (SECM) was used to probe the released $\mathrm{Fe}(\mathrm{CN})_{6}{ }^{4-}$ ions from PBV film with $\mathrm{Os}(\mathrm{bpy})_{3} \mathrm{Cl}_{2}$ as a mediator for the approaching process in $0.5 \mathrm{M} \mathrm{KCl}$ medium. Mass changes during the redox process of the film were also monitored in-situ by electrochemical quartz crystal microbalance (EQCM). The ion exchange and transport behavior was observed during CV cycling of the film of the SECM and EQCM. The insertion and extraction of anions were found to be potential-dependence. Moreover, the decrease in tip current of released $\mathrm{Fe}(\mathrm{CN})_{6}{ }^{4-}$ with increasing cycle number accounted for the ion exchange between $\mathrm{Fe}(\mathrm{CN})_{6}{ }^{4-}$ and $\mathrm{Cl}^{-}$in the $\mathrm{KCl}$ electrolyte. However, the $\mathrm{Fe}(\mathrm{CN})_{6}{ }^{4-} / \mathrm{Fe}(\mathrm{CN})_{6}{ }^{3-}$ redox couple was found to be highly stable between 0.0 and $0.5 \mathrm{~V}$ (vs. $\mathrm{Ag} / \mathrm{AgCl} /$ saturated $\mathrm{KCl}$ ) in the phosphate buffer solution. Therefore, the electrochemical property of $\mathrm{Fe}(\mathrm{CN})_{6}{ }^{4-} / \mathrm{Fe}(\mathrm{CN})_{6}{ }^{3-}$ redox couple was studied at different scan rates using $\mathrm{CV}$ technique. The peak currents were directly proportional to the scan rate as predicted for a surface confined diffusionless system. The surface coverage $(\Gamma)$ and the concentration of $\mathrm{Fe}(\mathrm{CN})_{6}{ }^{4-}$ were determined to be $1.88 \times 10^{-8} \mathrm{~mol} / \mathrm{cm}^{2}$ and $0.641 \mathrm{~mol} / \mathrm{dm}^{3}$, respectively. By neglecting cations incorporation during redox reaction of the PBV film and also based on the results obtained from energy-dispersive X-ray spectroscopy for the films of as-deposited, reduced and oxidized states, an ion exchange mechanism was proposed.
\end{abstract}

(c) 2008 Elsevier Ltd. All rights reserved.

\section{Introduction}

Once salts dissolve in solvents, dissociation would separate them into positively-charged cation and negative-charged anion, enabling the charge compensation for the electroactive materials with valence change by applying a potential. As far as an electroactive film is concerned, the charge transfer takes place within the film during the switching process. The electron would transfer at the interface between the film and the conducting substrate electrode, while the ion exchange would occur at the interface between the film and the bulk electrolyte for charge compensation. However, the current responses directly measured from the thin-film electrode do not reflect the ion transport. Therefore, indirect analytical instruments, which can be divided into internal and external analysis, have been utilized to probe the actual ion transport pro-

\footnotetext{
* Corresponding author. Tel.: +886 22366 0739; fax: +886223623040

E-mail address: kcho@ntu.edu.tw (K.-C. Ho).

1 ISE member.
}

cess. The internal methods provide information responded by the thin film itself, such as electrochemical quartz crystal microbalance (EQCM) [1-7] and ac impedance methods [7-9]. While the external methods investigate the ion exchange by the detector outside the film, such as elemental analysis [8,10], ellipsometry [11], probe beam deflection (PBD) [4,12], and scanning electrochemical microscopy (SECM) [13-18]. According to the above analysis, the ion movement during the redox process involves the ions incorporated within the film during polymerization and those from the electrolyte. Thus, the understanding of the ion exchange process can contribute to the realization of some electrochemical techniques such as the ion-selective electrodes or exploration of the problem from the viewpoint of mechanism.

SECM is an electrochemical scanning probe instrument to probe surface by the electrochemical reaction at the tip [19], and it has been used to obtain the detailed information about the ion exchange characteristics of various conducting polymers, including polypyrrole [15], polyaniline [16], and poly(3,4-ethylenedioxythiophene) [17,18]. The ultramicroelectrode (UME) tip in a SECM is used to detect the ions released from the 
film-covered substrate electrode so as to realize the possible ion movement. On the condition that the polymer film undergoes a redox reaction, the ion flux can be detected by another potentialcontrolled electrode. This feasibility was first brought up by Anson and co-workers [13,14].

Our earlier study on the organic polymer, poly(butyl viologen) (PBV), revealed that anions are heavily involved during the redox switching process [20]. PBV has three redox states which are di-cation $\left(\mathrm{PBV}^{2+}\right)$, radical-cation $\left(\mathrm{PBV}^{\bullet+}\right)$, and di-reduced state $\left(\mathrm{PBV}^{0}\right)$, and it is electropolymerized by applying a potential to the radical-cation state of its monomer. As a result of the polycationic property, it is definite that the counterions, i.e. anions, would incorporate along with $\mathrm{PBV}^{\bullet+}$ into the film for the charge compensation. Furthermore, the deposition solution of PBV contains ferrocyanide anions $\left(\mathrm{Fe}(\mathrm{CN})_{6}{ }^{4-}\right)$, which were added to improve the electrochemical properties and stability of the PBV thin-film. Accordingly, during the redox reaction of the as-deposited films, the $\mathrm{Fe}(\mathrm{CN})_{6}{ }^{4-}$ would exchange with the other anion in the electrolyte solution. This process was found to relate to the ionic size [21], which implies that a larger ion would be probably exchanged by a smaller one.

In this study, we are interested in probing the ion exchange at the PBV film-electrolyte interface by using a SECM. This allows us to realize the potential at which the release of $\mathrm{Fe}(\mathrm{CN})_{6}{ }^{4-}$ within the PBV occurs, and also cross-examine with the result of EQCM. Finally, an exchange mechanism would be proposed from the observations of the $\mathrm{Fe}(\mathrm{CN})_{6}{ }^{4-}$ leaving the film by SECM and energy-dispersive $\mathrm{X}$-ray spectroscopy (EDX). Once understanding the ion exchange mechanism of PBV films, it will benefit its applications through characteristic clarification.

\section{Experimental}

\subsection{Chemicals}

$\mathrm{KCl}, \mathrm{KH}_{2} \mathrm{PO}_{4}$, and $\mathrm{KH}_{2} \mathrm{PO}_{4}$ were all purchased from Aldrich and $\mathrm{K}_{4} \mathrm{Fe}(\mathrm{CN})_{6}$ was purchased from Fisher Scientific, and they were all reagent grade and used as received. Bis(4-cyano-1-pyridino)butane dibromide $\left(\mathrm{BVBr}_{2}\right)$ [20] and tris(2,2'-bipyridyl) osmium chloride $\left(\mathrm{Os}(\mathrm{bpy})_{3} \mathrm{Cl}_{2}\right)[22]$ were synthesized according to respective literature. All aqueous solutions were made with deionized water (DIW) of resistivity of ca. $18.2 \mathrm{M} \Omega \mathrm{cm}$. Experiments were all done at room temperature and in air.

\subsection{Preparation of PBV-modified electrodes}

The PBV thin-films were potentiostatically electropolymerized from $\mathrm{BVBr}_{2}$. The substrate electrodes used for SECM, EQCM, and EDX analysis were a $0.0314 \mathrm{~cm}^{2}$ platinum (Pt) disc electrode $(\mathrm{CHI})$, a $0.196 \mathrm{~cm}^{2}$ platinum electrode coated on the AT-cut quartz crystal with $9 \mathrm{MHz}$ (Seiko EG\&G), and $4 \mathrm{~cm}^{2}$ indium tin oxide (ITO) glass substrates (RiTdisplay Corporation, $R_{\mathrm{sh}}=10 \Omega / \square$ ), respectively. An aqueous medium containing $20 \mathrm{mM} \mathrm{BVBr}_{2}, 10 \mathrm{mM}$ $\mathrm{KH}_{2} \mathrm{PO}_{4}, 90 \mathrm{mM} \mathrm{K}_{2} \mathrm{HPO}_{4}$, and $100 \mathrm{mM} \mathrm{K} \mathrm{Fe}_{4}(\mathrm{CN})_{6}$ was used for the deposition of $\mathrm{Fe}(\mathrm{CN})_{6}{ }^{4-} / \mathrm{PBV}$ film at constant potential $(-0.75 \mathrm{~V}$ vs. $\mathrm{Ag} / \mathrm{AgCl} /$ saturated $\mathrm{KCl}$ ) until an expected charge capacity was reached and then stepping to $0 \mathrm{~V}$ for $180 \mathrm{~s}$. The resulting modified electrode were rinsed with DIW to remove the residual bath solutions and then stored in air.

\subsection{Apparatus and procedure}

For SECM monitoring, a four-electrode potentiostat (CHI, model 900B) was used to connect the tip and substrate electrodes. The PBV-modified substrate electrode was lodged in the bottom of a cell which consisted of a Teflon cup with a hole in the bottom and a Pt wire infixed in the cup as a counter electrode. A homemade $\mathrm{Ag} / \mathrm{AgCl} /$ saturated $\mathrm{KCl}$ reference electrode, which all potentials reported in this work are relative to, was put at the rim of the cup and the cell was filled with $0.5 \mathrm{M} \mathrm{KCl}$ and $5 \mathrm{mM} \mathrm{Os}(\mathrm{bpy})_{3} \mathrm{Cl}_{2}$ solution. The $10-\mu \mathrm{m}$-diameter Pt tip electrode ( $\mathrm{CHI}$ ) was then positioned above the PBV film at a distance of ca. $10 \mu \mathrm{m}$ by a positive feedback approaching process. The ratio of tip-substrate distance $(d)$ and tip radius ( $a$ ), e.g. $d / a$, is 2 . Afterward, the potential of the PBV-modified electrode was cycled between 0.0 and $-0.8 \mathrm{~V}$ at a scan rate of $10 \mathrm{mV} / \mathrm{s}$ and that of the tip was fixed at $0.4 \mathrm{~V}$ to detect the released $\mathrm{Fe}(\mathrm{CN})_{6}{ }^{4-}$ outside the film.

The ion transport behavior of the PBV film was characterized in $0.5 \mathrm{M} \mathrm{KCl}$ solution carried out in a three-electrode system using potentiostat/galvanostat (Eco Chemie, model Autolab PGSTAT30) for cyclic voltammetry (CV) scanning at a scan rate of $10 \mathrm{mV} / \mathrm{s}$ and quartz crystal analyzer (EG\&G, model QCA917) for in-situ EQCM measurement. Except the same reference electrode used in SECM analysis, the counter electrode used a Pt sheet $(4.0 \mathrm{~cm} \times 1.0 \mathrm{~cm})$ and the PBV-modified Pt electrode on the quartz crystal as a working electrode was enclosed by a Teflon holder and sealed against the solution using O-ring to prevent one side contact from the solution. The resulting resonant frequency change could convert into the mass change of the film by Sauerbrey equation [23]:

$\Delta m=\Delta f \frac{A \sqrt{\mu_{\mathrm{q}} \rho_{\mathrm{q}}}}{-2 f_{0}{ }^{2}}$

where $f_{0}$ is the resonant frequency of the fundamental mode of the crystal, $A$ is the surface area of the Pt electrode on the crystal $\left(0.196 \mathrm{~cm}^{2}\right), \mu_{\mathrm{q}}$ is the shear modulus of AT-cut quartz $\left(2.947 \times 10^{11} \mathrm{~g} \mathrm{~cm}^{-1} \mathrm{~s}^{-2}\right)$, and $\rho_{\mathrm{q}}$ is the density of quartz $\left(2.648 \mathrm{~g} \mathrm{~cm}^{-3}\right)$.

For EDX analysis, thick PBV films were electropolymerized and CV cycling in a three-electrode system as described in EQCM part, except the working electrode used an ITO glass since the peaks of Pt masked our expecting peaks. The PBV films were formed in the bath solution and cycled in a $0.5 \mathrm{M} \mathrm{KCl}$ solution so as to exchange $\mathrm{Fe}(\mathrm{CN})_{6}{ }^{4-}$ ions with chloride ions. Finally, they were washed with DIW and dried in air. In addition, at the last cycle, the films were then switched to 0.0 or $-0.8 \mathrm{~V}$ to obtain the oxidized or reduced films, respectively. The EDX analysis was performed by an energy dispersive X-ray spectrometer (Kevex Delta class 80000).

\section{Results and discussion}

\subsection{Redox properties of the $\mathrm{Fe}(\mathrm{CN})_{6}{ }^{4-} / \mathrm{PBV} / \mathrm{Pt}$ system}

During the electropolymerization process, the $\mathrm{Fe}(\mathrm{CN})_{6}{ }^{4-}$ were electrodeposited along with the positively charged PBV film. Nakahara and Wang [24] reported that the methyl viologen ion $\left(\mathrm{CH}_{2} \cdot \mathrm{NC}_{5} \mathrm{H}_{4} \cdot \mathrm{C}_{5} \mathrm{H}_{4} \mathrm{~N} \cdot \mathrm{CH}_{3}\right)^{2+}$ is a good electron acceptor because of the stability of its free radical ion discovered by Michaelis [25]. In aqueous solution, when it was mixed with electron donor such as $\mathrm{Fe}(\mathrm{CN})_{6}{ }^{4-}$ ions, a purple color was formed due to the formation of charge transfer complex [25]. Similar type of color change was also observed when butyl viologen monomer mixed with $\mathrm{Fe}(\mathrm{CN})_{6}{ }^{4-}$ ions in our case. This result indicates that $\mathrm{Fe}(\mathrm{CN})_{6}{ }^{4-}$ ions must have been attached with monomer through charge transfer complex and got over with monomer during polymerization. Therefore, the redox species of the polymer film also contains the $\mathrm{Fe}(\mathrm{CN})_{6}{ }^{4-}$ ions. Fig. 1 shows the $\mathrm{CV}$ of a $\mathrm{Fe}(\mathrm{CN})_{6}{ }^{4-} / \mathrm{PBV} / \mathrm{Pt}$ film scanned between 0.5 and $-0.8 \mathrm{~V}$ in $0.5 \mathrm{M} \mathrm{KCl}$ solution. The first redox couple with formal potential of $-0.45 \mathrm{~V}$ labeled as the peaks $\mathrm{I}_{\mathrm{p}}{ }^{\mathrm{a}}$ and $\mathrm{I}_{\mathrm{p}}{ }^{\mathrm{c}}$ is corresponding 


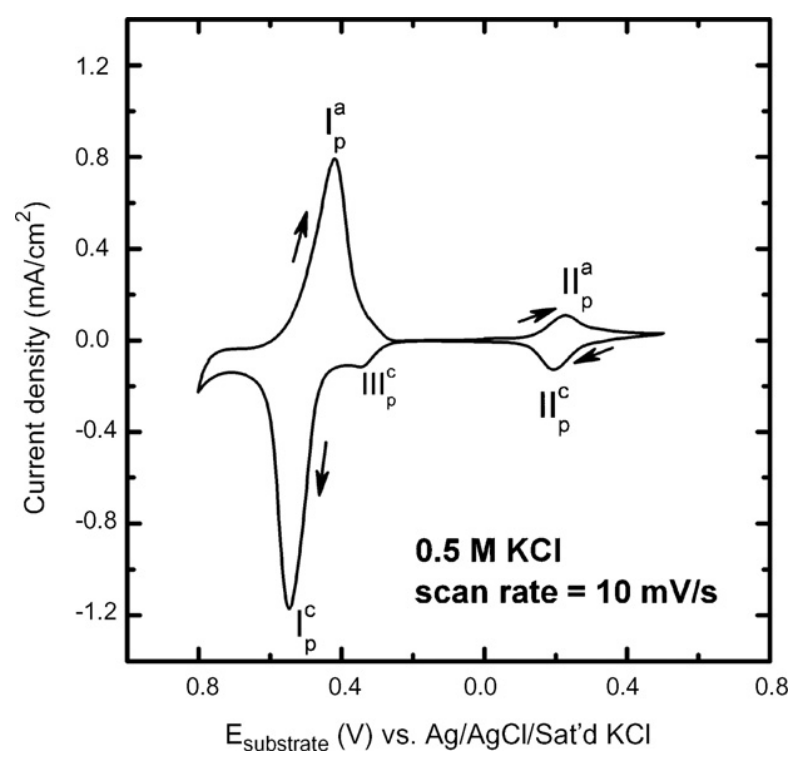

Fig. 1. Cyclic voltammogram of $\mathrm{Fe}(\mathrm{CN})_{6}{ }^{4-} / \mathrm{PBV}$ film in $0.5 \mathrm{M} \mathrm{KCl}$ solution at a scan rate of $10 \mathrm{mV} / \mathrm{s}$.

to the reversible electrochemical redox reaction of $\mathrm{PBV}^{2+}$ and $\mathrm{PBV}^{\bullet+}$. There is another redox couple at the positive potential $\left(\mathrm{II}_{\mathrm{p}}{ }^{\mathrm{a}}, \mathrm{II}_{\mathrm{p}}{ }^{\mathrm{c}}\right)$ appeared with formal potential of $0.25 \mathrm{~V}$, which resulted from the immobilized $\mathrm{Fe}(\mathrm{CN})_{6}{ }^{4-} / \mathrm{Fe}(\mathrm{CN})_{6}{ }^{3-}$ redox couple on the PBV film. In addition, it is noticed that there is a small reduction peak $\left(\mathrm{III}_{\mathrm{p}}{ }^{\mathrm{c}}\right)$ which is resulted from the reduction of residual oxygen in the solution [26] despite purging nitrogen into the solution.

Before the SECM analysis, the tip electrode should approach to the surface of the substrate by means of the redox reaction of the mediator. However, during the SECM analysis, the tip current was contributed only from the oxidation reaction of $\mathrm{Fe}(\mathrm{CN})_{6}{ }^{4-}$ but not from interference of mediator or other ions. Besides, the electrochemical behavior of PBV film was found to be anion-dependent based on our previous investigation [20]. Therefore, Os(bpy) ${ }_{3} \mathrm{Cl}_{2}$ was chosen as the mediator for the approaching process. The mediator contains the common anion species, i.e. chloride anion $\left(\mathrm{Cl}^{-}\right)$, compared with the $\mathrm{KCl}$ electrolyte, so as to avoid any possible influence on the electrochemistry of the PBV film. Moreover, the redox potential of $\mathrm{Os}(\mathrm{bpy})_{3}{ }^{2+/ 3+}$ is located at more positive potential compared with redox properties of PBV film and $\mathrm{Fe}(\mathrm{CN})_{6}{ }^{4-} / \mathrm{Fe}(\mathrm{CN})_{6}{ }^{3-}$, as shown in Fig. 2. Therefore, by setting the tip potential at $0.9 \mathrm{~V}$ and the substrate potential at $0.0 \mathrm{~V}$, a positive feedback during the tip approach could be obtained to precisely determine the location of the tip electrode. Furthermore, by setting the substrate potential at $0.0 \mathrm{~V}$, the oxidation of $\mathrm{Fe}(\mathrm{CN})_{6}{ }^{4-}$ anion as well as the reduction of PBV film could be avoided, thus the electrochemical properties of the film remained unaltered. After the tip was positioned at a distance of ca. $10 \mu \mathrm{m}$ above the PBV film, the substrate electrode began to scan between 0.0 and $-0.8 \mathrm{~V}$ to record the ion exchange process while the tip potential was also controlled at $0.4 \mathrm{~V}$ to oxidize the released $\mathrm{Fe}(\mathrm{CN})_{6}{ }^{4-}$, where the oxidation was diffusion control. According to Fig. 2, there was no current contributed from the $\mathrm{Os}$ (bpy) $3^{2+/ 3+}$ mediator at $0.4 \mathrm{~V}$, so the detecting current discussed in Sections 3.3 and 3.4 reflects only the flux of $\mathrm{Fe}(\mathrm{CN})_{6}{ }^{4-}$ ejected from the PBV film and reaching the tip surface. On the other hand, it is reported [15,27] that if the tip-substrate distance is small enough, e.g. $d / a<2$, the substrate current induced by the redox regeneration will be on the same order of magnitude as that of the tip current, thus the interference from the redox regeneration can not

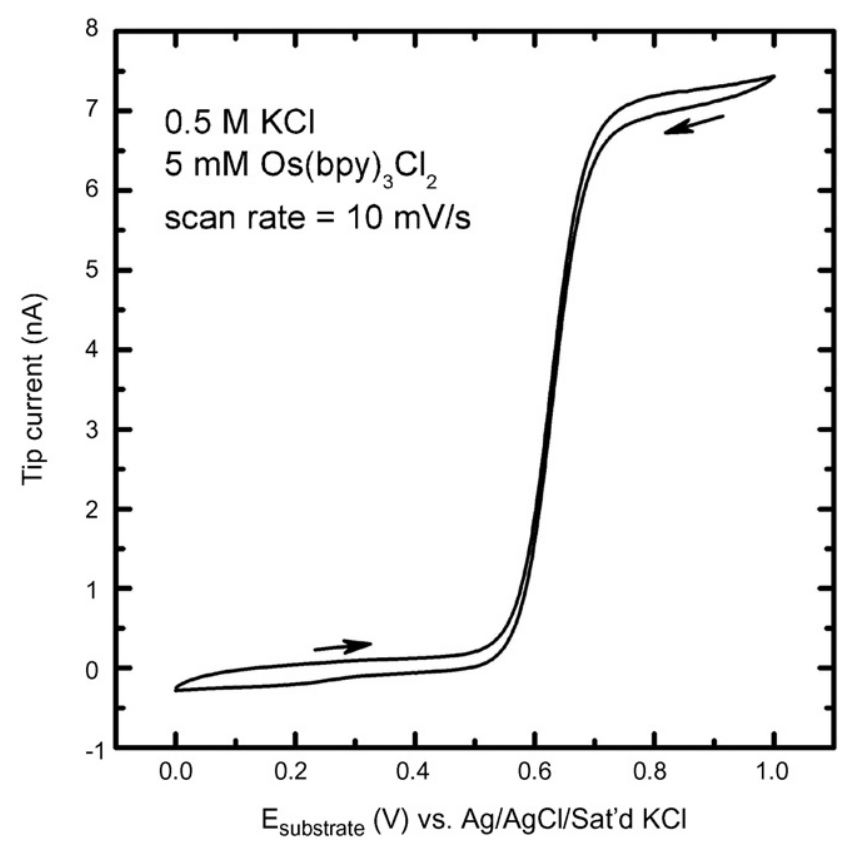

Fig. 2. Cyclic voltammogram of a $10 \mu \mathrm{m}$ diameter Pt tip electrode in $0.5 \mathrm{M} \mathrm{KCl}$ and $5 \mathrm{mM} \mathrm{Os}(\mathrm{bpy})_{3} \mathrm{Cl}_{2}$ solution at a scan rate of $10 \mathrm{mV} / \mathrm{s}$.

be neglected. Therefore, the ratio of $d / a$ was set at 2 to prevent the inaccuracy of collecting $\mathrm{Fe}(\mathrm{CN})_{6}{ }^{4-}$.

\subsection{Characteristics of the $\mathrm{Fe}(\mathrm{CN})_{6}{ }^{4-}$ ions in $\mathrm{PBV}$ film}

The stability of $\mathrm{Fe}(\mathrm{CN})_{6}{ }^{4-}$ ions confined in the PBV film was evaluated by monitoring $\mathrm{CV}$ responses. $\mathrm{Fe}(\mathrm{CN})_{6}{ }^{4-}$ immobilized in PBV film-coated electrode was immersed in $0.5 \mathrm{M}$ phosphate buffer solution and the consecutive CVs were recorded, as shown in Fig. 3. The oxidation and reduction peaks of the $\mathrm{Fe}(\mathrm{CN})_{6}{ }^{4-}$ ion confined in PBV film disappeared quickly for few consecutive cycles between 0.5 and $-0.8 \mathrm{~V}$ in the $\mathrm{KCl}$ solution, however, in the case of phosphate buffer, the peak current decreased much slower and remained almost constant for further cycling. Quantitatively speaking, the oxidation charge of $\mathrm{Fe}(\mathrm{CN})_{6}{ }^{4-}$ reduced to half of its original value at the 2 nd cycle and almost diminished after five cycles in $\mathrm{KCl}$ solution, as shown in the inset of Fig. 3(a). On the other hand, in a phosphate buffer solution, the oxidation charge at the 20th cycle still remained $80 \%$ of its initial value, as evidenced in the inset of Fig. 3(b). This result shows that the ion exchange property of chloride ions is high enough to replace the $\mathrm{Fe}(\mathrm{CN})_{6}{ }^{4-}$ in PBV film than that of phosphate ions. Therefore, the characteristics of $\mathrm{Fe}(\mathrm{CN})_{6}{ }^{4-}$ in PBV film can be studied in the phosphate buffer medium with the potential ranges from 0.0 to $0.5 \mathrm{~V}$ in which the redox reaction of $\mathrm{Fe}(\mathrm{CN})_{6}{ }^{4-} / \mathrm{Fe}(\mathrm{CN})_{6}{ }^{3-}$ is highly stable.

Fig. 4 shows the cyclic voltammograms of the $\mathrm{Fe}(\mathrm{CN})_{6}{ }^{4-}$ confined in PBV film in 0.1 M phosphate buffer solution ( $\mathrm{pH} 7.0$ ) at various scan rates. The voltammetric peaks are typical of a surfaceimmobilized redox couple with a formal potential $0.232 \mathrm{~V}$. Besides, the formal potential was almost independent of the potential sweep rates below $300 \mathrm{mV} / \mathrm{s}$, suggesting facile charge transfer kinetics over this range of sweep rates. The peak-to-peak potential separation $\left(\Delta E_{\mathrm{p}}=E_{\mathrm{p}, \mathrm{a}}-E_{\mathrm{p}, \mathrm{c}}\right)$ is small, and about $3 \mathrm{mV}$ for sweep rates below $5 \mathrm{mV} / \mathrm{s}$. Moreover, the peak separation begins to increase, indicating the limitation arising from the charge transfer kinetics. Also, the electrochemical responses of the $\mathrm{Fe}(\mathrm{CN})_{6}{ }^{4-} / \mathrm{PBV}$ film were those anticipated for a surface-confined redox couple, because the peak currents were directly proportional to the scan rate (see inset 

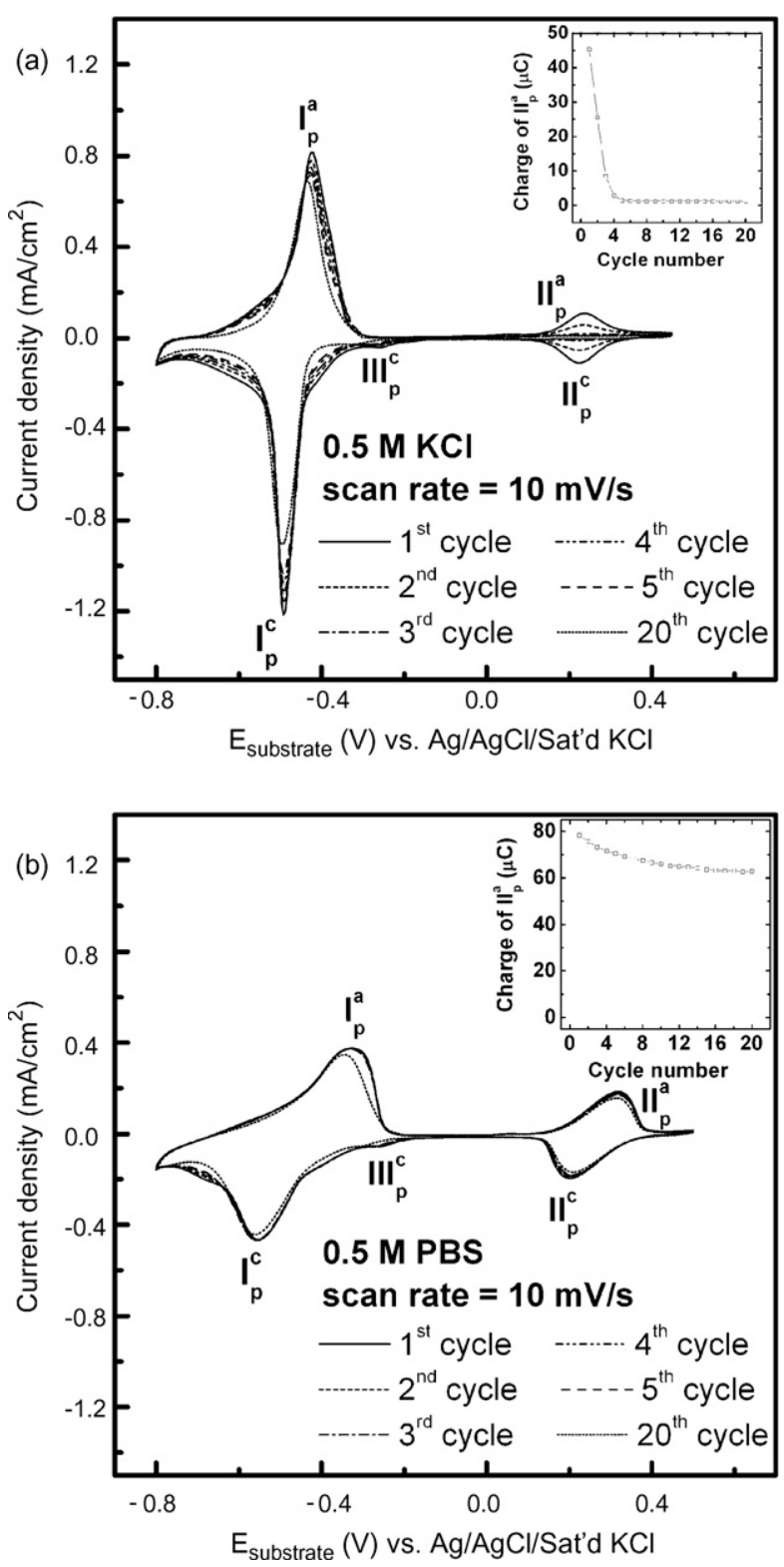

Fig. 3. Cyclic voltammograms of $\mathrm{Fe}(\mathrm{CN})_{6}{ }^{4-} / \mathrm{PBV}$ film in (a) $0.5 \mathrm{M} \mathrm{KCl}$ solution and (b) $0.5 \mathrm{M}$ phosphate buffer solution with $1 \mathrm{st}, 2 \mathrm{nd}, 3 \mathrm{rd}, 4 \mathrm{th}, 5$ th, and 20 th cycle. Both insets show the charge amount of the peak $\mathrm{II}_{\mathrm{p}}{ }^{\mathrm{a}}$ against cycle numbers.

A of Fig. 4), as predicted for a diffusionless system. The ratio of cathodic to anodic peak currents remains constant up to $300 \mathrm{mV} / \mathrm{s}$. The surface coverage of $\mathrm{Fe}(\mathrm{CN})_{6}{ }^{4-}$ immobilized onto the film $(\Gamma)$ was calculated with the following equation [27]:

$\Gamma=\frac{Q_{\mathrm{a}}}{n F A_{\mathrm{e}}}$

where $Q_{a}$ is the charge under the anodic peak, obtained by integrating the area under the anodic peak in cyclic voltammograms at a slow scan rate $(5 \mathrm{mV} / \mathrm{s})$ in the phosphate buffer solution (see inset B of Fig. 4), $n$ is the number of electrons transferred ( $n=1)$, and $A_{\mathrm{e}}$ is the electrode's geometric area. The amounts of $Q_{\mathrm{a}}, \Gamma$ and $C$ (the concentration of redox molecule $\mathrm{Fe}(\mathrm{CN})_{6}{ }^{4-}$ ) present within the film are $57.04 \mu \mathrm{C}, 1.88 \times 10^{-8} \mathrm{~mol} / \mathrm{cm}^{2}$ and $0.641 \mathrm{~mol} / \mathrm{dm}^{3}$, respectively.

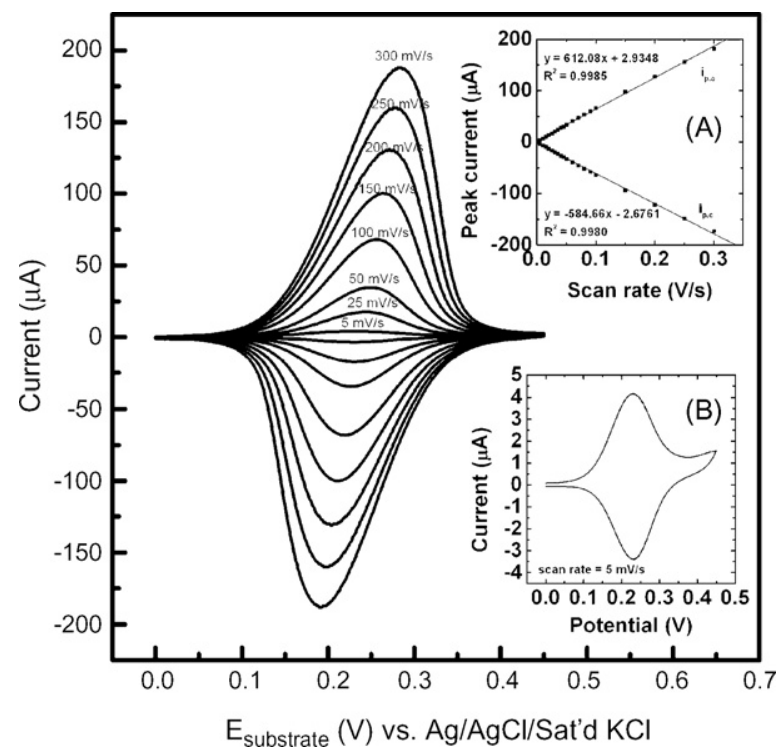

Fig. 4. Cyclic voltammogram of $\mathrm{Fe}(\mathrm{CN})_{6}{ }^{4-}$ confined in PBV film in $0.5 \mathrm{M}$ phosphate buffer solution at various scan rates. Inset $A$ shows the peak currents as a function of the scan rate. Inset $\mathrm{B}$ shows the $\mathrm{CV}$ at $5 \mathrm{mV} / \mathrm{s}$.

\subsection{SECM detection of the released species}

Since EQCM technique is sensitive to very small mass changes in the ranges from 1 to $100 \mu \mathrm{g}$ [28], it has been greatly employed to investigate the ion transport properties within thin films during electrochemical studies. However, the mass changes resulted from transport of cations, anions, and solvents simply show a net contribution, which means a lack of identification of single species. In this case, the exchange between $\mathrm{Fe}(\mathrm{CN})_{6}{ }^{4-}$ and $\mathrm{Cl}^{-}$accompanying water transport which cannot be identified by EQCM, consequently, SECM is introduced to observe the release of $\mathrm{Fe}(\mathrm{CN})_{6}{ }^{4-}$ species due to its redox nature.

Fig. 5 shows simultaneously the results of SECM detection and the EQCM mass change during the first CV cycling of the $\mathrm{Fe}(\mathrm{CN})_{6}{ }^{4-} / \mathrm{PBV}$ film in $0.5 \mathrm{M} \mathrm{KCl}$. With the reduction potential applied to the film-deposited substrate electrode, initially there

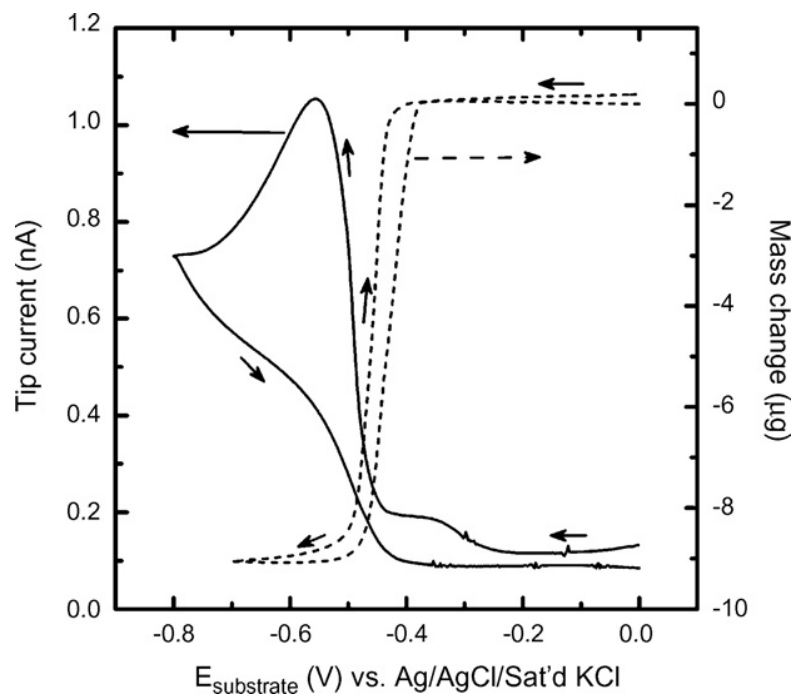

Fig. 5. SECM tip current detection of released ferrocyanide anions (solid line) and in-situ mass change of a PBV film (dashed line) as a function of the CV scanning potentials of PBV film in a $0.5 \mathrm{M} \mathrm{KCl}$ and $5 \mathrm{mM} \mathrm{Os}(\mathrm{bpy})_{3} \mathrm{Cl}_{2}$ solution at a scan rate of $10 \mathrm{mV} / \mathrm{s}$. Tip potential $=0.4 \mathrm{~V}$. 


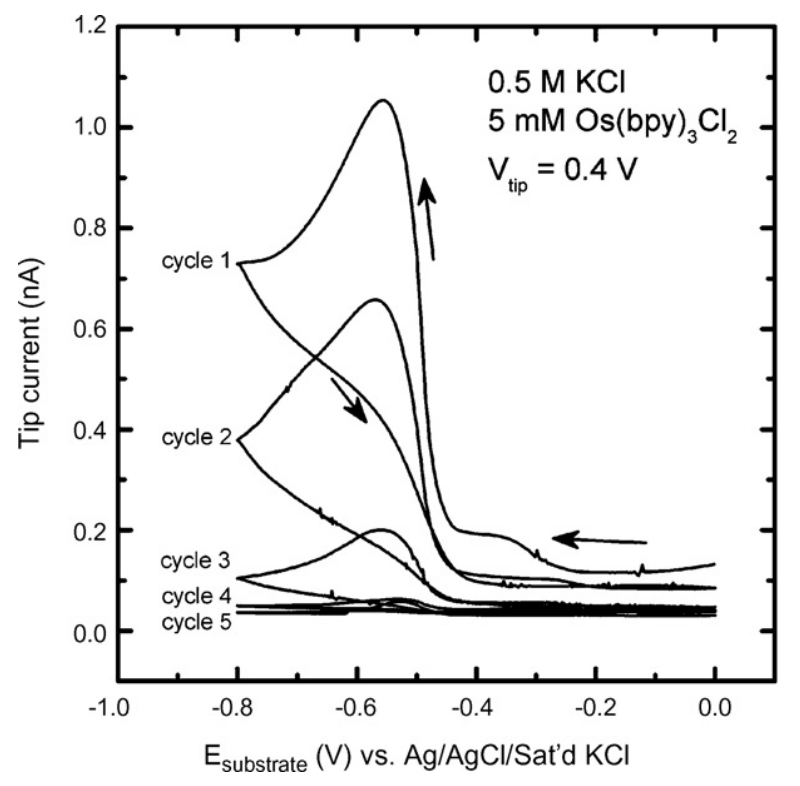

Fig. 6. SECM tip current detection of released ferrocyanide anions as a function of the $\mathrm{CV}$ scanning potentials of $\mathrm{PBV}$ film in a $0.5 \mathrm{M} \mathrm{KCl}$ and $5 \mathrm{mM} \mathrm{Os}(\text { bpy })_{3} \mathrm{Cl}_{2}$ solution at a scan rate of $10 \mathrm{mV} / \mathrm{s}$ for the first five cycles. Tip potential $=0.4 \mathrm{~V}$.

was no significant change in tip current or appreciable mass change observed until the potential reached at ca. $-0.43 \mathrm{~V}$. The small reaction across from -0.3 to $-0.4 \mathrm{~V}$ which corresponds to $\mathrm{III}_{\mathrm{p}}{ }^{\mathrm{c}}$ in Fig. 1 should be attributed from the oxygen re-oxidation. The EQCM revealed that the $\mathrm{Fe}(\mathrm{CN})_{6}{ }^{4-}$ began to release resulted in a loss of mass at ca. $-0.43 \mathrm{~V}$, at which potential the onset current at the tip was also observed. From EQCM and SECM results, one can understand that a significant amount of $\mathrm{Fe}(\mathrm{CN})_{6}{ }^{4-}$ was released and detected at ca. $-0.55 \mathrm{~V}$. The good consistency between SECM and EQCM results has provided a strong evidence that the ejection of anions from the PBV film begins at ca. $-0.43 \mathrm{~V}$. Moreover, the tip still detected the $\mathrm{Fe}(\mathrm{CN})_{6}{ }^{4-}$ in the reverse scan of the PBV film as shown in Fig. 5, and similar result was also observed in the earlier report [17]. This result implies that the released redox species persisted in the solution layer surrounded by the tip and the substrate for some time after releasing from the film. Consequently, the shape for the tip current vs. substrate potential can be explained by the SECM and EQCM data. It has been reported that the ionic flux varies as a function of the substrate potential [29], so the concentration of $\mathrm{Fe}(\mathrm{CN})_{6}{ }^{4-}$ around the tip will also change during the potential sweep at the substrate. From the observed tip current in Fig. 5, it can be seen that the flux increases from the onset potential $(-0.43 \mathrm{~V})$ to the peak potential $(-0.55 \mathrm{~V})$, leading to the increase of the $\mathrm{Fe}(\mathrm{CN})_{6}{ }^{4-}$ concentration, thus increasing the oxidation current at the tip. Afterwards, the peak position shows a turning point, an indication of flux decrease. When the release of $\mathrm{Fe}(\mathrm{CN})_{6}{ }^{4-}$ is over,

Table 1

A comparison of the remained and released charges of $\mathrm{Fe}(\mathrm{CN})_{6}{ }^{4-}$, as determined, respectively, by the CV data performed to the substrate and the SECM's tip current collection

\begin{tabular}{llll}
\hline Method & Cycles & Charge remained $(C)$ & Nearest charge ratio \\
\hline CV (substrate) & 1st & $45.3 \times 10^{-6}$ & 1 \\
& 2nd & $25.6 \times 10^{-6}$ & 0.56 \\
& 3rd & $8.5 \times 10^{-6}$ & 0.19 \\
Method & Cycles & Charge released (C) & Nearest charge ratio \\
SECM (tip) & 1st & $48.9 \times 10^{-9}$ & 1 \\
& 2nd & $24.7 \times 10^{-9}$ & 0.51 \\
& 3rd & $4.6 \times 10^{-9}$ & 0.09 \\
\hline
\end{tabular}

i.e. during the reverse scan, the persistence of $\mathrm{Fe}(\mathrm{CN})_{6}{ }^{4-}$ is gradually consumed and the current returns to the background value. Thus, it is possible to observe the anion transport from the SECM analysis. In fact, the anion transport even can be described using the shape of the tip current vs. the substrate potential. Accordingly, it is inferred that the shape of the $i-E$ curve depends only on the concentration profile of $\mathrm{Fe}(\mathrm{CN})_{6}{ }^{4-}$ vs. time. The concentration profile of the released species vs. time is determined by the dynamic condition of the substrate. The ratio of $d / a$ is an important factor in determining the tip current, and the magnitude of the current should remain the same as long as this ratio is fixed.

Furthermore, Bard and co-workers [15] had demonstrated that there is some time delay in the tip response resulted from the diffusion and migration of detecting ion or cation incorporation. Cation incorporation means a cation insertion to electroneutralize the film instead of anion ejection. They found that the bromide ion could
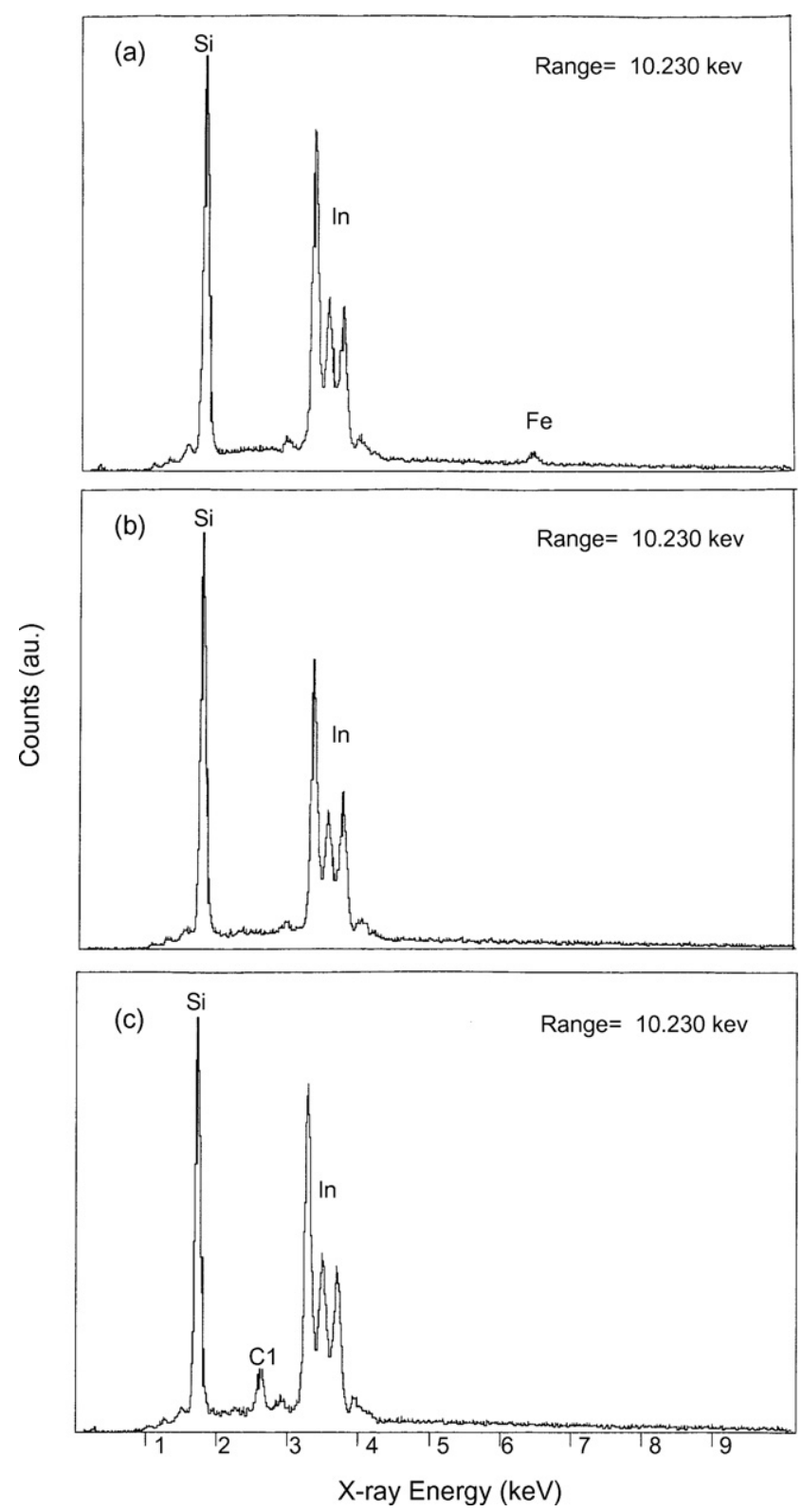

Fig. 7. EDX spectra of PBV films deposited on ITO glass substrates: (a) the asdeposited film, (b) the first reduced film at $-0.8 \mathrm{~V}$ in a $0.5 \mathrm{M} \mathrm{KCl}$ solution and (c) the oxidized film at $0.0 \mathrm{~V}$ after one $\mathrm{CV}$ cycling in $0.5 \mathrm{M} \mathrm{KCl}$ solution. 
not be detected simultaneously during the reduction of polypyrrole film and continued on the reverse scan. In our case, however, it is clear that the reduction current of PBV film begins at ca. $-0.43 \mathrm{~V}$ (Fig. 1) which is also corresponding to the potential for the release of $\mathrm{Fe}(\mathrm{CN})_{6}{ }^{4-}$ in Fig. 5. This means that the onset potential for the electrochemical response obtained in this study is well synchronized with those obtained from EQCM and SECM. In an earlier report [30], the $\mathrm{Fe}(\mathrm{CN})_{6}{ }^{4-}$ with the diffusion coefficient of $6 \times 10^{-6} \mathrm{~cm}^{2} / \mathrm{s}$ diffusing through a $300 \mathrm{~nm}$-thick PBV film and approximately took only $0.1 \mathrm{~s}$ to reach the tip kept at a $10 \mu \mathrm{m}$ from the surface of the PBV film (this time value is estimated from the results of Bard and co-workers [31]). However, in such a low scan rate, $10 \mathrm{mV} / \mathrm{s}$, the diffusion effect existed but being insignificant compared with the potential went by, as they suggested [15]. As for the cation incorporation which was explained as the main reason for the time delay in Bard's case does not play a part in the ion transport of PBV film due to a good synchronization of tip and substrate responses.

\subsection{Ion exchange process of the $\mathrm{Fe}(\mathrm{CN})_{6}{ }^{4-} / \mathrm{PBV}$ film}

Fig. 6 shows the SECM detection of $\mathrm{Fe}(\mathrm{CN})_{6}{ }^{4-}$ along with the five consecutive $\mathrm{CV}$ scans of the PBV film. It was observed that the amounts of $\mathrm{Fe}(\mathrm{CN})_{6}{ }^{4-}$ released decreased with cycle number, indicating that the ion exchange process was faster at the first cycle than the consecutive cycles. At the 5th cycle, there was almost no current response. By integrating the tip current at the 5th cycle and kept this accumulated charge as the reference. With respect to the 5th cycle, the amount of $\mathrm{Fe}(\mathrm{CN})_{6}{ }^{4-}$ ions released from the substrate was calculated from the accumulated charge of each cycle. It should be mentioned here that the currents in the forward and backward directions are all considered in our calculation for the charge release of $\mathrm{Fe}(\mathrm{CN})_{6}{ }^{4-}$ at each cycle. The results show that $48.9,24.7$ and $4.6 \mathrm{nC}$ were detected for oxidation of $\mathrm{Fe}(\mathrm{CN})_{6}{ }^{4-}$, during first, second and third cycle, respectively. The 4 th and 5 th cycles were comparatively less. Since the background current is very small, there is no additional current contributes from the redox regeneration and the release of $\mathrm{Fe}(\mathrm{CN})_{6}{ }^{4-}$ at subsequent cycles become negligible. The amount of the released $\mathrm{Fe}(\mathrm{CN})_{6}{ }^{4-}$ can be determined from the columbic charge by integrating the current vs. time at each cycle, thus it is possible to describe the ion exchange reaction of the PBV film based on the released amounts. The remained and released charges of $\mathrm{Fe}(\mathrm{CN})_{6}{ }^{4-}$, as measured by $\mathrm{CV}$ (Fig. 3(a)) and SECM (Fig. 6), respectively, are listed in Table 1. It can be seen from Table 1 that the nearest ratio of the charge is very close

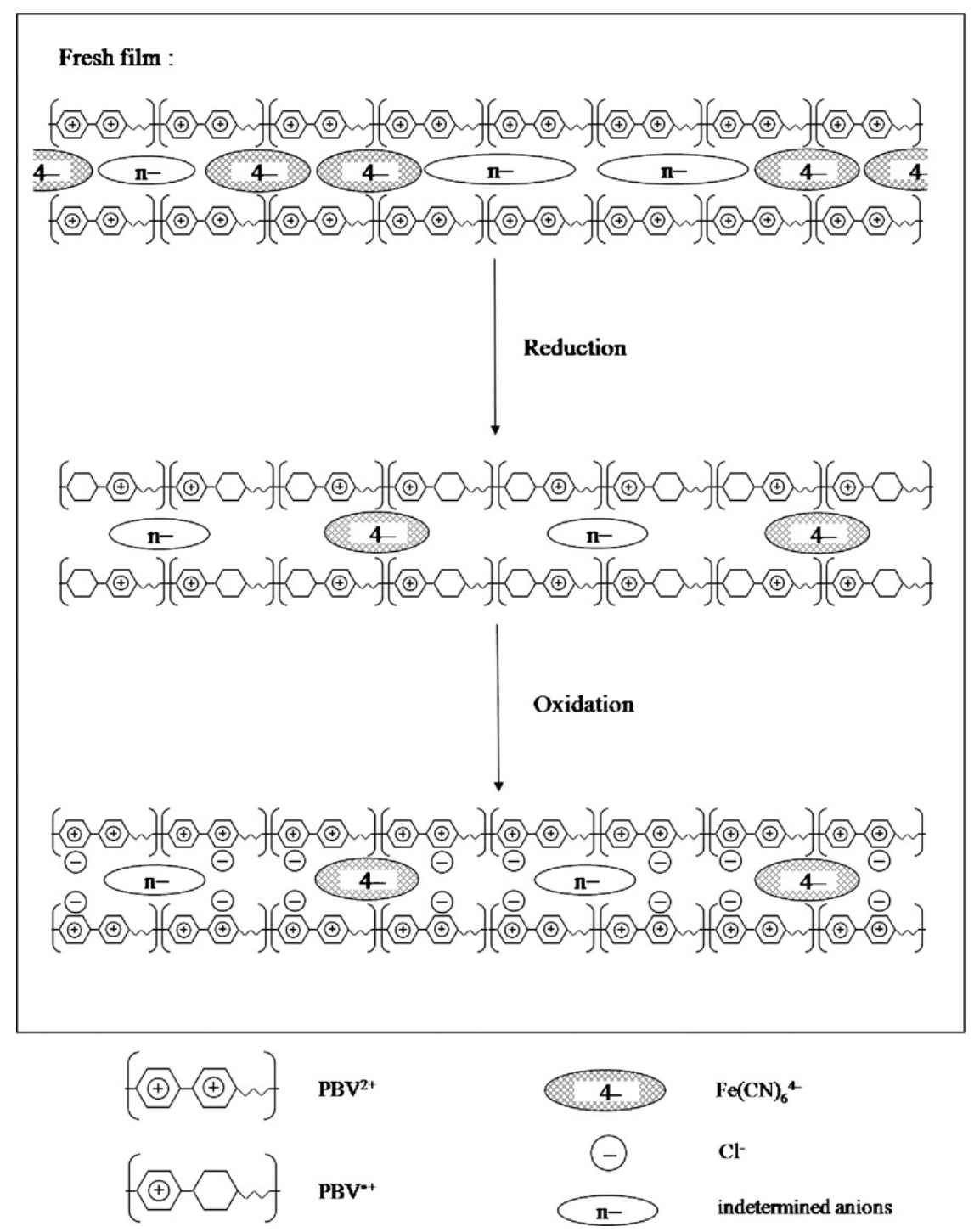

Fig. 8. Schematic for the ion exchange during the first redox process of the PBV film. 
at each cycle, regardless of the method of measurement. Therefore, the estimation from the SECM measurement can be ensured.

Moreover, the replacement of the $\mathrm{Fe}(\mathrm{CN})_{6}{ }^{4-}$ ions by the $\mathrm{Cl}^{-}$during electrochemical redox reaction of the PBV film was confirmed with EDX analysis for different conditions such as before and after cycling in $\mathrm{KCl}$ solution as shown in Fig. 7. It deserves to be mentioned that the signals of $\mathrm{Si}$ and In from the ITO glass substrate are unavoidable because of the $300 \mathrm{~nm}$-thick PBV thin-film allowing the electron source to go through. In Fig. 7(a), it is clear that the as-deposited film contained $\mathrm{Fe}(\mathrm{CN})_{6}{ }^{4-}$ as the counter ion resulting in the Fe signal. However, the reduction of PBV film expelled the ferrocyanides anion within the film, so the reduced film showed no Fe signal, as shown in Fig. 7(b). The detection amounts of the Fe after 2nd cycle is not feasible since the residual amounts after the first reduction are too small to sense by X-ray. Therefore, there may be some uncertainty for the detected amounts after the 2nd cycle due to much smaller amounts, so the following mechanism of ion exchange process is proposed based on the results obtained from the first two cycles to ensure the validity. The evidence of $\mathrm{Cl}^{-}$ exchanging with $\mathrm{Fe}(\mathrm{CN})_{6}{ }^{4-}$ is shown in Fig. 7(c). The oxidized PBV film resulted in an anion-insertion, consequently, the peak of $\mathrm{Cl}$ appeared.

According to the above observation, we propose a sketch of ion exchange mechanism for the PBV film during the first and second redox reaction as following, as written in Eq. (6), so the released amounts of the $\mathrm{Fe}(\mathrm{CN})_{6}{ }^{4-}$ for the following cycles are negligible. This supports that the reaction of PBV film involves only $\mathrm{Cl}^{-}$as described previously [20] after a completed ion exchange process.

\section{Conclusions}

The present study of $\mathrm{PBV} / \mathrm{Fe}(\mathrm{CN})_{6}{ }^{4-}$ films in $\mathrm{KCl}$ aqueous solution reveals an ion exchange process led by anion transport during electrochemical switching. For an under-growing PBV film, the polycationic characteristic results in a counter-ion capture for charge compensation, e.g. $\mathrm{Fe}(\mathrm{CN})_{6}{ }^{4-}$ in this case. Whenever a driving force such as electrical field is applied to the modified-electrode in the presence of chloride anions in the bulk solution, the ion exchange proceeds to expel the electroactive $\mathrm{Fe}(\mathrm{CN})_{6}{ }^{4-}$. Therefore, the releasing process of $\mathrm{Fe}(\mathrm{CN})_{6}{ }^{4-}$ can be investigated by a SECM tip probing at the film-electrolyte interface. The results of SECM representing the detection outside the film and EQCM representing the mass change of the film seem to be consistent and synchronized with the release of $\mathrm{Fe}(\mathrm{CN})_{6}{ }^{4-}$. During the reduction of a PBV film, the release of $\mathrm{Fe}(\mathrm{CN})_{6}{ }^{4-}$ begins at ca. $-0.43 \mathrm{~V}$ and reaches a maximum flux at ca. $-0.55 \mathrm{~V}$. When the scanning potential is reversed to oxidize the film, certain $\mathrm{Fe}(\mathrm{CN})_{6}{ }^{4-}$ still persists around the tip for some time. Besides, the synchronization

$$
\begin{aligned}
& \left\{\left[\mathrm{PBV}^{2+}\right]\left[\frac{1}{4} \mathrm{Fe}(\mathrm{CN})_{6}{ }^{4-}\right]\left[\frac{1}{n} \mathrm{X}^{n-}\right]\right\}+\mathrm{e}^{-} \rightarrow\left\{\left[\mathrm{PBV}^{\bullet+}\right]\left[\frac{1}{8} \mathrm{Fe}(\mathrm{CN})_{6}{ }^{4-}\right]\left[\frac{1}{2 n} \mathrm{X}^{n-}\right]\right\}+\frac{1}{2 n} \mathrm{X}^{n-}+\frac{1}{8} \mathrm{Fe}(\mathrm{CN})_{6}{ }^{4-} \\
& \left\{\left[\mathrm{PBV}^{\bullet+}\right]\left[\frac{1}{8} \mathrm{Fe}(\mathrm{CN})_{6}{ }^{4-}\right]\left[\frac{1}{2 n} \mathrm{X}^{n-}\right]\right\}+\mathrm{Cl}^{-} \rightarrow\left\{\left[\mathrm{PBV}^{2+}\right]\left[\frac{1}{8} \mathrm{Fe}(\mathrm{CN})_{6}{ }^{4-}\right]\left[\frac{1}{2 n} \mathrm{X}^{n-}\right]\left[\mathrm{Cl}^{-}\right]\right\}+\mathrm{e}^{-} \\
& \left\{\left[\mathrm{PBV}^{2+}\right]\left[\frac{1}{8} \mathrm{Fe}(\mathrm{CN})_{6}{ }^{4-}\right]\left[\frac{1}{2 n} \mathrm{X}^{n-}\right]\left[\mathrm{Cl}^{-}\right]\right\}+\mathrm{e}^{-} \rightarrow\left\{\left[\mathrm{PBV}^{\bullet+}\right]\left[\frac{1}{16} \mathrm{Fe}(\mathrm{CN})_{6}{ }^{4-}\right]\left[\frac{1}{4 n} \mathrm{X}^{n-}\right]\left[\frac{1}{2} \mathrm{Cl}^{-}\right]\right\}+\frac{1}{4 n} \mathrm{X}^{n-}+\frac{1}{2} \mathrm{Cl}^{-}+\frac{1}{16}{\mathrm{Fe}(\mathrm{CN})_{6}{ }^{4-}}^{-} \\
& \left\{\left[\mathrm{PBV}^{\bullet+}\right]\left[\frac{1}{16} \mathrm{Fe}(\mathrm{CN})_{6}{ }^{4-}\right]\left[\frac{1}{4 n} \mathrm{X}^{n-}\right]\left[\frac{1}{2} \mathrm{Cl}^{-}\right]\right\}+\mathrm{Cl}^{-} \rightarrow\left\{\left[\mathrm{PBV}^{2+}\right]\left[\frac{1}{16} \mathrm{Fe}(\mathrm{CN})_{6}{ }^{4-}\right]\left[\frac{1}{4 n} \mathrm{X}^{n-}\right]\left[\frac{3}{2} \mathrm{Cl}^{-}\right]\right\}+\mathrm{e}^{-}
\end{aligned}
$$

where Eqs. (3) and (4) and Eqs. (5) and (6) represent the first and second redox cycle, respectively. The initial stoichiometry of the $\mathrm{Fe}(\mathrm{CN})_{6}{ }^{4-} / \mathrm{PBV}$ is determined by the electroactive coverages from Fig. 1 , which are ca. $1.1 \times 10^{-7} \mathrm{~mol} / \mathrm{cm}^{2}$ and ca. $2.8 \times 10^{-8} \mathrm{~mol} / \mathrm{cm}^{2}$ for the PBV film and $\mathrm{Fe}(\mathrm{CN})_{6}{ }^{4-}$, respectively. Thus, we can infer that one $\mathrm{PBV}^{2+}$ molecule carries about $1 / 4 \mathrm{Fe}(\mathrm{CN})_{6}{ }^{4-}$ and $1 / n$ indeterminable anion, denoted as $\mathrm{X}^{n-}$. The deposition solution contains other anions, $\mathrm{X}^{n-}$, in addition to $\mathrm{Fe}(\mathrm{CN})_{6}{ }^{4-}$, but they are not electroactive in the potential range of interest and cannot be determined quantitatively. The redox reactions then proceeded under the principle of charge balance. As for the reduction process (Eqs. (3) and (5)), the remaining and released amounts of the $\mathrm{Fe}(\mathrm{CN})_{6}{ }^{4-}$ at the 2 nd cycle are almost half of its 1 st cycle, as shown in Table 1. This implies that the released amount of the $\mathrm{Fe}(\mathrm{CN})_{6}{ }^{4-}$ should also roughly be half of its original amount within the film. Based on the charge balance, the released amount of the $\mathrm{X}^{n-}$ has to be nearly half of its original value. Besides, the reduction process involves only anion-ejection but no cation-incorporation as mentioned earlier. As for the oxidation, even though there is a possibility for $\mathrm{Fe}(\mathrm{CN})_{6}{ }^{4-}$ being re-inserted into the film, the concentration of the $\mathrm{Fe}(\mathrm{CN})_{6}{ }^{4-}$ is relatively small as compared to that of the $\mathrm{Cl}^{-}$, leading to only chloride-insertion as written in Eqs. (4) and (6). The above descriptions about the ion exchange for the first redox process can be illustrated with a scheme outlined in Fig. 8. A part of $\mathrm{Fe}(\mathrm{CN})_{6}{ }^{4-}$ and $\mathrm{X}^{n-}$ are delocalized once the redox property of the PBV film is changed from di-cation to radical-cation state, and then they are expelled out of the film due to an increasingly negative bias. Afterward, when applying an anodic potential, the bulk $\mathrm{Cl}^{-}$are taken up for charge balance. After two redox cycles, the stoichiometry of the released $\mathrm{Fe}(\mathrm{CN})_{6}{ }^{4-}$ becomes much smaller than that of the $\mathrm{Cl}^{-}$ between SECM and EQCM reveals that the $\mathrm{Fe}(\mathrm{CN})_{6}{ }^{4-}$ is detected instantaneously after the release, so the ion transport predominates by anions without cation incorporation. Furthermore, the amounts of released $\mathrm{Fe}(\mathrm{CN})_{6}{ }^{4-}$ decrease with cycling number of the PBV film, which implies that $\mathrm{Fe}(\mathrm{CN})_{6}{ }^{4-}$ would be exchanged by $\mathrm{Cl}^{-}$and then diffusing to the bulk solution. By identifying status of the film through EDX analysis and the detecting amounts of $\mathrm{Fe}(\mathrm{CN})_{6}{ }^{4-}$ through SECM, the reaction mechanism of PBV film during ion exchange process can be proposed for the first two redox switchings. However, the $\mathrm{Fe}(\mathrm{CN})_{6}{ }^{4-} / \mathrm{Fe}(\mathrm{CN})_{6}{ }^{3-}$ redox couple was found to be more stable between 0.5 and $-0.8 \mathrm{~V}$ in the phosphate buffer solution than that in $\mathrm{KCl}$ solution, presumably due to different anion sizes and mobilities. Thus, the electrochemical properties of the $\mathrm{Fe}(\mathrm{CN})_{6}{ }^{4-} / \mathrm{Fe}(\mathrm{CN})_{6}{ }^{3-}$ redox couple was investigated in the phosphate buffer solution. The surface coverage $(\Gamma)$ and the concentration of $\mathrm{Fe}(\mathrm{CN})_{6}{ }^{4-}$ were calculated and determined to be $1.88 \times 10^{-8} \mathrm{~mol} / \mathrm{cm}^{2}$ and $0.641 \mathrm{~mol} / \mathrm{dm}^{3}$, respectively.

\section{Acknowledgement}

The financial support provided by the National Science Council of Taiwan, under grant number NSC 95-2221-E-002-353-MY2, is gratefully acknowledged.

\section{References}

[1] J.R. Reynolds, M. Pyo, Y.J. Qiu, J. Electrochem. Soc. 141 (1994) 35.

[2] S.L. de Albuquerque Maranhão, R.M. Torresi, J. Electrochem. Soc. 146 (1999) 4179.

[3] E. Shouji, D.A. Buttry, Electrochim. Acta 45 (2000) 3757. 
[4] H.M. French, M.J. Henderson, A.R. Hillman, E. Vieil, J. Phys. Chem. 500 (2001) 192.

[5] H. Varela, R.L. Bruno, R.M. Torresi, Polymer 44 (2003) 5369.

[6] A. Bund, S. Neudeck, J. Phys. Chem. 108 (2004) 17845

[7] W. Plieth, A. Bund, U. Rammelt, S. Neudeck, L. Duc, Electrochim. Acta 51 (2006) 2366.

[8] X. Ren, P.G. Pickup, J. Phys. Chem. 97 (1993) 5356

[9] X. Ren, P.G. Pickup, Electrochim. Acta 41 (1996) 1877.

[10] A.J.F. Romero, J.J.L. Cascales, T.F. Otero, J. Phys. Chem. B 109 (2005) 907.

[11] C. Lee, J. Kwak, A.J. Bard, J. Electrochem. Soc. 136 (1989) 3720.

12] P. Novák, R. Kötz, O. Haas, J. Electrochem. Soc. 140 (1993) 37.

[13] J. Kwak, F.C. Anson, Anal. Chem. 64 (1992) 250.

[14] C. Lee, F.C. Anson, Anal. Chem. 64 (1992) 528.

[15] M. Arca, M.V. Mirkin, A.J. Bard, J. Phys. Chem. 99 (1995) 5040

[16] G. Denuault, M.H.T. Frank, L.M. Peter, Faraday Discuss. 94 (1992) 23.

[17] V. Syritski, R.E. Gyurcsányi, A. Öpik, K. Tóth, Synth. Met. 152 (2005) 133.
[18] N. Yang, C.G. Zoski, Langmuir 22 (2006) 10338.

[19] A.J. Bard, F.R.F. Fan, J. Kwak, O. Lev, Anal. Chem. 61 (1989) 132.

[20] Y.C. Hsu, K.C. Ho, J. New Mater. Electrochem. Syst. 8 (2005) 49.

[21] C. Weidlich, K.M. Mangold, K. Jüttner, Electrochim. Acta 50 (2005) 1547.

[22] J.G. Gaudiello, P.G. Bradley, K.A. Norton, W.H. Woodruff, A.J. Bard, Inorg. Chem. 23 (1984) 3

[23] G. Sauerbrey, Z. Phys. 155 (1959) 206.

[24] A. Nakahara, J.H. Wang, J. Phys. Chem. 67 (1963) 496.

[25] L. Michaelis, Chem. Rev. 16 (1935) 243.

[26] F. Rauwel, D. Thévenot, J. Electroanal. Chem. 75 (1977) 579.

[27] A.J. Bard, L.R. Faulkner, Electrochemical Methods: Fundamentals and Applications, 2nd ed., Wiley, NY, 2001, p. 626.

[28] D.A. Buttry, M.D. Ward, Chem. Rev. 92 (1992) 1355

[29] G. Maia, R.M. Torresi, E.A. Ticianelli, F.C. Nart, J. Phys. Chem. 100 (1996) 15910.

[30] M.V. Stackelberg, M. Pilgram, W. Toome, Z. Elektrochem. 57 (1953) 342.

[31] M.V. Mirkin, M. Arca, A.J. Bard, J. Phys. Chem. 97 (1993) 10790. 